\title{
PENGARUH PENAMBAHAN SORBITOL DAN KALSIUM KARBONAT TERHADAP KARAKTERISTIK DAN SIFAT BIODEGRADASI FILM DARI PATI KULIT PISANG
}

\author{
Senny Widyaningsih, Dwi Kartika, Yuni Tri Nurhayati \\ Program Studi Kimia, Fakultas Sains dan Teknik, Unsoed, Purwokerto \\ Email : sennysetiadi@yahoo.com
}

\begin{abstract}
ABSTRAK
Kulit pisang merupakan limbah dari industri pembuatan keripik pisang. Kandungan pati dalam kulit pisang dapat dimanfaatkan untuk dibuat menjadi film biogedradable. Untuk memperbaiki sifat film yang dihasilkan maka ditambahkan sorbitol sebagai plasticizer dan kalsium karbonat sebagai filler. Hasil penelitian menunjukkan bahwa film berbahan dasar pati dari kulit pisang memiliki densitas antara 3,11-6,12 $\mathrm{g} / \mathrm{cm}^{3}$; higroskopisitas antara 3,55-7,59\%; laju transmisi uap air antara $0,0017-0,0021 \mathrm{~g} / \mathrm{jam} \mathrm{cm} \mathrm{cm}^{2}$; kelarutan dalam air antara 2,54-59,01\%; kelarutan dalam asam 4,05-87,86\%; daya regang antara 2,73-179,61 MPa; panjang putus antara 1,95-19,81 MPa; ketahanan sobek antara 2,50-26,32 MPa; dan pada uji biodegradasi dalam tanah mengalami penurunan berat film antara $5,73-85,08 \%$.
\end{abstract}

Kata kunci : film, biodegradable, sorbitol, kalsium karbonat

\section{THE EFFECT OF SORBITOL AND POTASSIUM CARBONATE ADDITION TO CHARACTERISTIC AND BIODEGRADABLE OF FILM BANANA SKIN STARCH}

\begin{abstract}
Banana skin is a waste from crispy chips of banana production industry. Starch content from banana skin can be made to biodegradable film. In order to repaire the characteristic film, it needs additive. The additive is sorbitol as plasticizer and sodium carbonate as filler. The results showed that the film had $3.11-6.12 \mathrm{~g} / \mathrm{cm}^{3}$ of density, $3.55-7.59 \%$ of hygroscopicity, $0.0017-0.0021 \mathrm{~g} / \mathrm{jam} \mathrm{cm}^{2}$ of water vapour of transmission rate (WVTR), 2.54-59.01\% of water solubility, $4.05-87.86 \%$ of acidic solubility, 2.73-179.61 $\mathrm{MPa}$ of tensile strength, $1.95-19.81 \mathrm{MPa}$ of elongation at break, and $5.73-85.08 \%$ of tear resistence. Biodegradable test showed that the range of film weight loss was $5.73-85.08 \%$.
\end{abstract}

Keywords : film, biodegradable, sorbitol, sodium carbonate 


\section{PENDAHULUAN}

Plastik mulai dikenal masyarakat sejak abad ke-19. Kebutuhan akan plastik semakin meningkat dari waktu ke waktu. Kebutuhan plastik masyarakat Indonesia tahun 2002 sekitar 1,9 juta ton kemudian meningkat menjadi 2,1 juta ton di tahun 2003 dan di tahun 2004 meningkat lagi menjadi 2,3 juta ton (Darni, 2008).

Jenis plastik yang beredar di masyarakat merupakan plastik sintetik dari bahan baku minyak bumi yang terbatas jumlahnya dan tidak dapat diperbaharui. Plastik jenis ini tidak dapat terdegradasi oleh mikroorganisme atau sukar dirombak secara hayati (nonbiodegradable) di lingkungan karena mikroorganisme tidak mampu mengubah dan mensintesis enzim yang khusus untuk mendegradasi polimer berbahan dasar petrokimia (Darni, 2008).

Banyak penelitian telah mencoba mencari bahan dasar pembuatan plastik ramah lingkungan atau dikenal dengan istilah bioplastik (plastic biodegradable). Plastik jenis ini merupakan plastik yang dapat diuraikan oleh jamur atau mikroorganisme di dalam tanah sehingga akan mengurangi dampak negatif yang ditimbulkan oleh plastik sintetik. Bioplastik merupakan plastik yang dapat diperbaharui karena senyawa-senyawa penyusunnya berasal dari tanaman seperti pati, selulosa, dan lignin serta hewan seperti kasein, protein dan lipid (Averous, 2004).

Kulit pisang dapat dimanfaatkan sebagai bahan baku pembuatan bioplastik karena kulit pisang mengandung pati. Kulit pisang merupakan limbah karena sisa produksi makanan ringan (seperti sriping pisang, sale pisang, dan lain-lain) yang biasanya hanya dijadikan sebagai pakan ternak. Komposisi kulit pisang yaitu air 68,90\%, karbohidrat 18,50\%, lemak $2,11 \%$, protein $0,32 \%$ dan komposisi kandungan kimia lainnya (Munadjim, 1983).
Bioplastik berbahan dasar pati memiliki kekuatan mekanik yang rendah sehingga diperlukan zat tambahan untuk memperbaiki hal tersebut. Platicizer sering digunakan untuk memperbaiki sifat elastisitas dan mengurangi sifat barrier film dari pati (Gontard et al., 1993). McHugh dan Krochta (1994), menyatakan bahwa poliol seperti sorbitol dan gliserol adalah plasticizer yang cukup baik untuk mengurangi ikatan hidrogen internal sehingga akan meningkatkan jarak intermolekul. Penggunaan sorbitol sebagai plasticizer diketahui lebih efektif, sehingga dihasilkan film dengan permeabilitas oksigen yang lebih rendah bila dibandingkan dengan menggunakan gliserol. Oleh karena itu pada penelitian ini yang digunakan sebagai plasticizer adalah sorbitol.

Selain itu penambahan bahan pengisi seperti kalsium karbonat $\left(\mathrm{CaCO}_{3}\right)$ juga diperlukan untuk mengatasi kekurangan sifat film seperti kekuatan sifat film. Berdasarkan fungsinya bahan pengisi digunakan untuk menekan biaya produksi apabila harganya lebih murah dibandingkan harga polimernya. Penambahan bahan pengisi dapat meningkatkan kekakuan plastik yang terlalu lentur, meningkatkan kekuatan, mengurangi kelarutan dan kecenderungan untuk bengkok. Kalsium karbonat memiliki harga yang relatif lebih murah dibandingkan dengan bahan pengisi lain.

\section{Pengujian sifat biodegradable} juga dilakukan untuk mengetahui keteruraian film dari pati kulit pisang. Beberapa faktor yang mempengaruhi tingkat biodegradabilitas plastik setelah kontak dengan mikroba yakni sifat hidrofob, bahan aditif, proses produksi, struktur polimer, morfologi dan berat molekul bahan plastik. Makin besar bobot molekul suatu bahan makin rendah biodegradabilitasnya. Bentuk film memiliki tingkat biodegradabilitas paling rendah. Reaksi degradasi kimia dalam 
polimer linier menyebabkan turunnya berat molekul atau pemendekan panjang rantai (Surdia, 2000).

\section{METODE PENELITIAN}

Bahan-bahan yang digunakan pada penelitian ini yaitu pati dari kulit pisang mentah, sorbitol, kalsium karbonat, pereaksi molish, asam sulfat pekat, larutan iod encer, dan $\mathrm{NaCl}$. Peralatan yang digunakan meliputi peralatan gelas, hot plate stirrer, dan alat uji tarik merk Zwick/Z0.5.

\section{a. Pembuatan film}

Langkah pertama dalam pembuatan film adalah mengisolasi pati dari kulit pisang. Kulit pisang dicuci, dipotong-potong, dan dihancurkan. Kulit pisang yang telah lumat kemudian disaring dan diperas menggunakan kain penyaring ke dalam wadah hingga ampas tidak mengeluarkan air perasan lagi. Filtrat yang dihasilkan kemudian didekantasi (diendapkan) selama 24-48 jam hingga pati mengendap sempurna. Cairan supernatan dibuang dan endapannya dicuci berulang-ulang dengan air hingga diperoleh endapan pati yang lebih jernih. Kemudian endapan pati dikeringkan menggunakan oven pada suhu $\pm 50^{\circ} \mathrm{C}$ selama 2 jam hingga kering. Endapan serbuk pati yang sudah kering kemudian dihaluskan.

Untuk menguji pati yang dihasilkan dilakukan uji Molish dan uji iod. Uji Molish dilakukan dengan cara larutan pati kulit pisang sebanyak $5 \mathrm{~mL}$ dimasukkan kedalam tabung reaksi dan ditambahkan 2 tetes pereaksi Molish dan dikocok merata. Secara hati-hati $2 \mathrm{~mL}$ $\mathrm{H}_{2} \mathrm{SO}_{4}$ pekat ditambahkan kedalam tabung reaksi tersebut, sehingga menghasilkan dua lapisan cairan dalam tabung reaksi dimana larutan contoh akan berada di lapisan atas. Cincin berwarna merah ungu pada batas kedua cairan menujukkan adanya karbohidrat dalam sanpel. Sedangkan untuk uji iod dilakukan dengan cara sampel pati dari kulit pisang mentah sebanyak 0,5 gram dimasukkan kedalam papan uji, ditambahkan satu tetes lautan iod encer. Kemudian dicampur secara merata. Timbulnya warna biru menujukkan adanya pati dalam sampel.

Karakterisasi pati yang dihasilkan meliputi kadar air dan kadar abu (AOAC, 1995). Penentuan kadar air didasarkan pada perbedaan berat sampel sebelum dan sesudah dikeringkan. Cawan porselin yang digunakan dikeringkan terlebih dahulu kira-kira 1 jam pada suhu $105^{\circ} \mathrm{C}$, lalu didinginkan dalam desikator selama 30 menit dan ditimbang sehingga beratnya tetap. Sampel ditimbang kirakira 2 gram dalam cawan tersebut, dikeringkan dalam oven pada suhu $100-105^{\circ} \mathrm{C}$ selama 5 jam atau beratnya tetap. Cawan yang berisi sampel didinginkan di dalam desikator selama 30 menit lalu ditimbang hingga beratnya tetap. Kadar air ditentukan dengan menghitung selisih berat per berat awal dikalikan $100 \%$.

Penentuan kadar abu didasarkan dengan menimbang sisa mineral sebagai hasil pembakaran bahan organik pada suhu sekitar $550^{\circ} \mathrm{C}$, lalu didinginkan selama 30 menit didalam desikator dan ditimbang hingga didapatkan berat tetap. sampel ditimbang sebanyak 2 gram, dimasukkan kedalam cawan porselin dan dipijarkan di atas nyala api pembakar Bunsen hingga tidak berasap lagi. Setelah dimasukkan kedalam furnance dengan suhu $650^{\circ} \mathrm{C}$ selama \pm 12 jam kemudian cawan didinginkan selama 30 menit pada desikator, setelah itu ditimbang hingga didapatkan berat tetap. Kadar abu ditentukan dengan menghitung selisih berat per berat awal dikalikan $100 \%$.

Langkah berikutnya adalah pembuatan film dengan cara melarutkan pati dengan air kemudian dipanaskan disertai penambahan kalsium karbonat. Setelah terjadi gelatinisasi dilakukan 
penambahan sorbitol. Kemudian setelah dingin larutan dituang dalam cetakan dan dikeringkan.

\section{b. Karakteristik film}

Film yang dihasilkan dilakukan karakterisasi untuk mengetahui sifat fisik dan mekaniknya. Pengujian sifat fisik meliputi densitas, higroskopisitas, laju transmisi uap air (WVTR), kelarutan dalam air, dan kelarutan dalam asam.

Penentuan rapat massa (densitas) film dilakukan dengan cara film dipotong dengan ukuran dan tebal tertentu, kemudian dihitung volumenya. Potongan film ditimbang dan rapat massa film ditentukan dengan membagi rapat potongan uji dengan volumenya $\left(\mathrm{g} / \mathrm{cm}^{3}\right)$.

Penentuan sifat higroskopisitas dilakukan untuk mengkaji sifat hidrofil suatu film bioplastik. Cawan petri dibersihkan dan ditimbang, selanjutnya cawan tersebut digunakan untuk menimbang produk seberat 1,5 gram. Cawan petri yang telah berisi produk selanjutnya dimasukkan dalam stoples yang berisi air. Volume air dalam stoples yang digunakan yaitu setinggi dasar cawan petri yang berisi produk. Produk pada cawan dijaga agar tidak kontak dengan air, sehingga cawan petri yang berisi produk disangga dengan cawan petri lainnya pada posisi terbalik.. Stoples ditutup rapat selama 4 jam, kemudian sampel diambil, ditimbang, dan ditentukan higroskopisitasnya dengan cara menentukan selisih berat per berat awal dikalikan $100 \%$.

Laju Transmisi Uap Air (water
vapour transmission rate/WVTR)
ditentukan dengan cara film yang akan
diuji dilapisi pada cawan yang berisi 10
gram gel silika kering dan ditempatkan
pada stoples plastik, yang didalamnya
berisi larutan $\mathrm{NaCl}$ jenuh (RH $\pm 75 \%$ ),
uap air yang terdifusi melaui film akan
diserap oleh gel silika sehingga akan
menambah berat gel silika tersebut.

Penimbangan dilakukan setiap satu jam, penimbangan ini dilakukan hingga jam ke-10. Data yang diperoleh dibuat persamaan regresi linier, sehingga diperoleh garis slope. Laju transmisi uap air (water vapour transmission rate/WTVR) dihitung dengan membagi slope kenaikan berat cawan terhadap luas permukaan film.

Penentuan kelarutan dalam air bertujuan untuk memprediksi kestabilan bioplastik terhadap pengaruh air. Berikut ini adalah langkah-langkah yang harus dilakukan yaitu produk bioplastik dipotong berbentuk lingkaran dengan diameter $2 \mathrm{~cm}$, sebanyak dua buah. Potongan uji dikeringkan pada suhu $105^{\circ} \mathrm{C}$ selama 24 jam. Potongan uji ditimbang dan selanjutnya direndam dalam air distilasi sebanyak $50 \mathrm{~mL}$ selama 24 jam pada suhu $25^{\circ} \mathrm{C}$. Selama proses perendaman, potongan uji secara periodik digoyang perlahan-lahan. Potongan uji dikeringkan pada suhu $105^{\circ} \mathrm{C}$ selama 24 jam kemudian ditimbang. Kelarutan dalam air dihitung dengan membagi selisih berat dengan berat awal dikalikan $100 \%$.

Kelarutan dalam asam dilakukan untuk memprediksi kestabilan bioplastik terhadap hidrolisis oleh senyawa asam yang kemungkinan keluar dari bahan pangan selama penyimpanan. Prosedur penentuan kelarutan dalam asam sama seperti kelarutan dalam air, hanya saja bahan pelarut yang digunakan pada prosedur ini menggunakan $\mathrm{HCl} 1 \mathrm{~N}$.

Pengujian sifat mekanik meliputi daya regang, perpanjangan putus, dan ketahanan sobek. Pengujian dilakukan menggunakan alat uji tarik. Film dipotong berbentuk dayung dengan cetakan khusus (super dumbbell cutter), kemudian dipasang pada rahang alat. Alat dioperasikan, sehingga terbaca gaya yang diberikan sampai bioplastik putus /robek. Alat uji tarik memberikan data gaya maksimum yang digunakan sampai film 
putus, perpanjangan film, dan ketahanan sobek.

\section{c. Sifat biodegradable film}

Sifat biodegradable film diuji dengan cara mengubur film dalam tanah dengan kelembaban relative $70 \%$. Pengujian biodegradable dilakukan dengan menimbang film sebelum dan sesudah penguburan dalam tanah untuk diketahui berat susut film. Analisis data dilakukan menggunakan metode Duncan Multiple Range Test (DMRT) pada taraf kesalahan 5\%.

\section{HASIL DAN PEMBAHASAN}

\section{a. Pembuatan film}

Pati yang dihasilkan dari bahan dasar kulit pisang berwarna putih kecokelatan seperti terlihat pada Gambar 1. Hasil pada uji Molish ditandai dengan terbentuknya cincin berwarna merah ungu pada batas kedua cairan, dan pada uji iod ditandai dengan adanya warna biru pada sampel setelah ditambahkan iod pada sampel. Hal ini menunjukkan bahwa sampel mengandung karbohidrat.

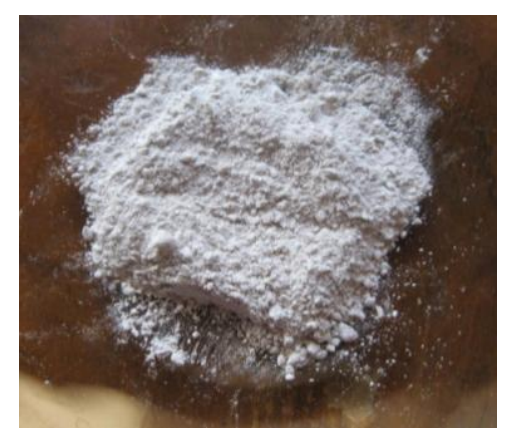

Gambar 1. Pati Kulit Pisang

Persentase kadar air dan abu pati kulit pisang berturut-turut sebesar $0,15 \%$ dan $0,98 \%$. Jumlah air dalam bahan akan mempengaruhi daya tahan bahan terhadap kerusakan yang disebabkan oleh mikroba maupun serangga. Berdasarkan hasil yang didapatkan kadar air dalam sampel relatif kecil sehingga cukup untuk menahan kerusakan akibat mikroba maupun serangga.

\section{b. Karakteristik film}

Film yang dihasilkan pada penelitian ini berwarna putih kecoklatan. Karakteristik film yang pertama adalah densitas. Densitas merupakan nilai yang menunjukkan massa bahan per satuan volume $\left(\mathrm{g} / \mathrm{m}^{3}\right)$. Hasil analisis uji $\mathrm{F}$ ( sidik ragam) pada densitas menunjukkan bahwa adanya variasi komposisi penambahan sorbitol dan kalsium karbonat memberikan pengaruh sangat nyata. Gambar 2 menunjukkan dengan adanya penambahan sorbitol dan kalsium karbonat pada berbagai variasi konsentrasi penambahan mempengaruhi nilai densitas. Penambahan kalsium karbonat dan sorbitol menghasilkan nilai densitas lebih besar. Densitas berbanding lurus dengan massa suatu bahan, sehingga semakin besar massa suatu bahan maka nilai densitas semakin besar. Berdasarkan pengamatan dari berbagai variasi komposisi penambahan sorbitol dan kalsium karbonat perlakuan T2N2 (penambahan $0,4 \%$ kalsium karbonat dan $40 \%$ sorbitol b/b pati) menghasilkan nilai densitas terbesar yaitu sebesar 6,12 $\mathrm{g} / \mathrm{cm}^{3}$.

Higroskopisitas adalah
kemampuan suatu bahan untuk melakukan penyerapan uap air dari lingkungan. Semakin besar higroskopisitas, maka akan mempengaruhi ketahanan dari bahan yang disimpan oleh film yang dihasilkan. Hasil analisis uji F (sidik ragam) pada higroskopisitas menunjukkan bahwa variasi penambahan sorbitol dan kalsium karbonat berpengaruh sangat beda nyata. Semakin banyak sorbitol dan kalsium karbonat yang ditambahkan nilai higroskopisitas film semakin besar. Berikut ini adalah Gambar 3 yang memperlihatkan sifat bioplastik berbahan dasar pati dengan variasi komposisi sorbitol dan kalsium karbonat 
higroskopisitas. Persentase higroskopis $3,55-7,59 \%$.

film dari pati kulit pisang berkisar antara

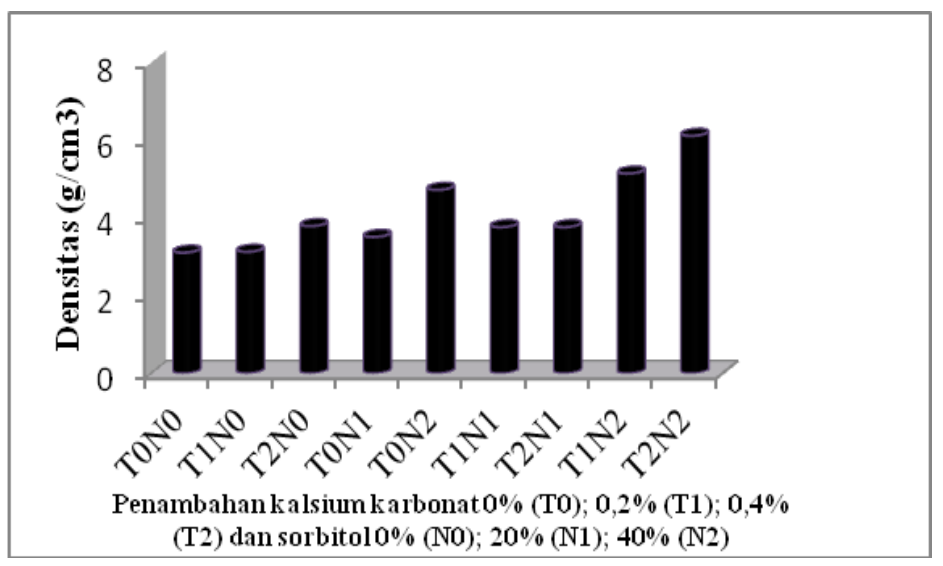

Gambar 2. Diagram pengaruh penambahan sorbitol dan kalsium karbonat terhadap densitas film

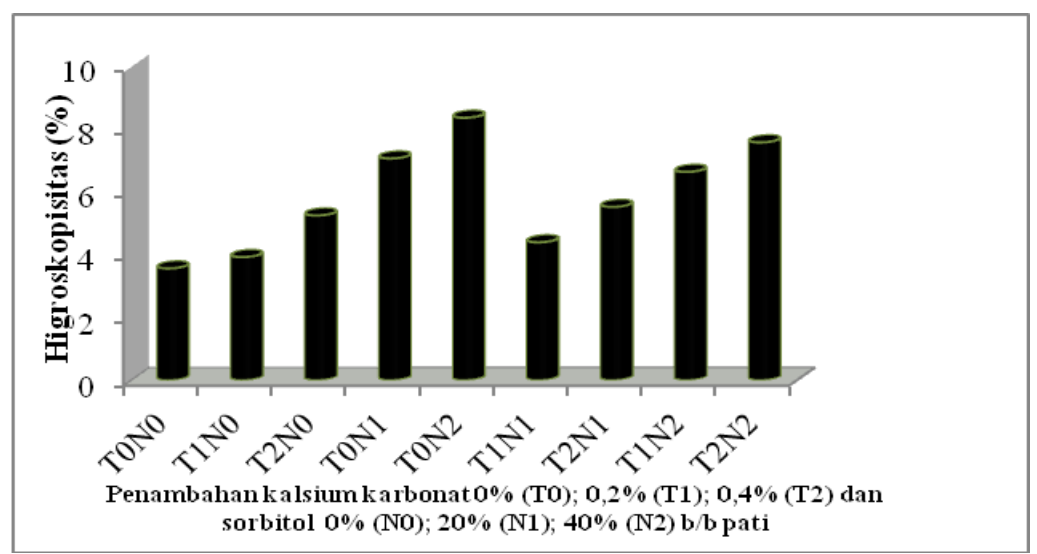

Gambar 3. Diagram pengaruh penambahan sorbitol dan kalsium karbonat terhadap higroskopisitas film

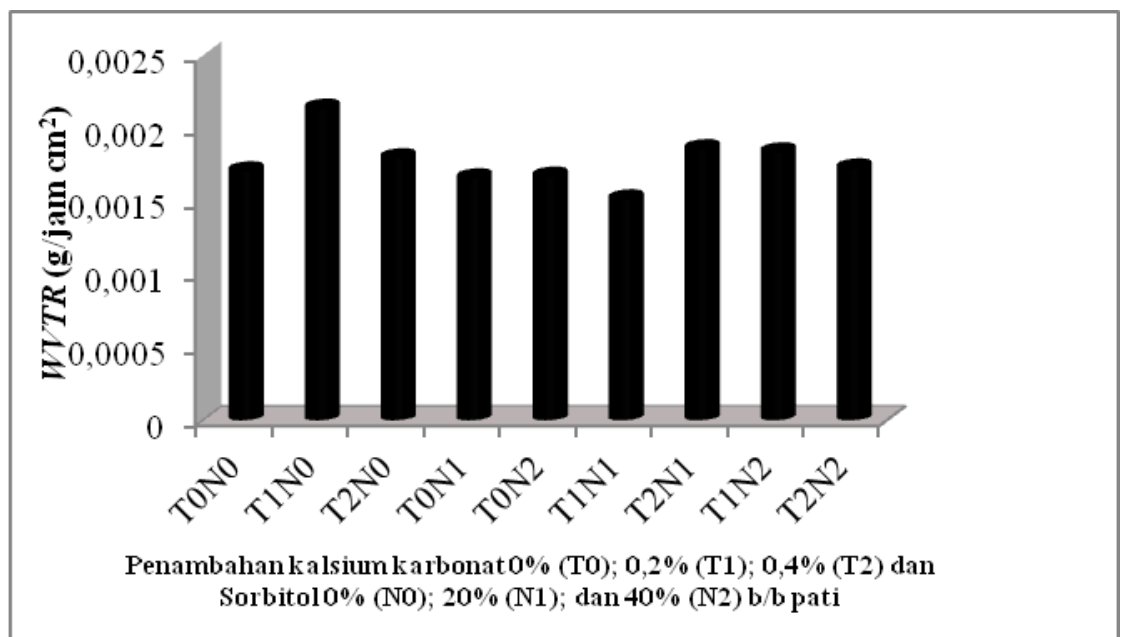

Gambar 4. Diagram pengaruh penambahan sorbitol dan kalsium karbonat terhadap WVTR film 
Pengukuran laju transmisi uap air suatu bahan merupakan faktor yang penting dalam menilai permeabilitas film terhadap uap air. Laju transmisi uap air yang dihasilkan berkisar antara 0,00167-0,00214 g/jam $\mathrm{cm}^{2}$. Hasil analisis uji $\mathrm{F}$ (sidik ragam) laju transmisi uap air menunjukkan sangat beda nyata. Gambar 4 menunjukkan bahwa adanya penambahan variasi komposisi sorbitol dan kalsium karbonat pada film berbahan dasar pati dari kulit pisang mempengaruhi sifat laju transmisi uap air. Menurut McHugh dan Krochta (1994), laju transmisi uap air suatu bahan dipengaruhi oleh sifat kimia dan struktur bahan pembentuk, konsentrasi plasticizer dan kondisi lingkungan seperti kelembaban dan temperatur. Gelembung udara yang terdapat pada lapisan dapat meningkatkan laju transmisi uap air. Peningkatan nilai laju transmisi uap air dapat juga disebabkan oleh bertambahnya komponen hidrofilik yang terdapat pada film sehingga memudahkan uap air melewatinya. Menurut Santoso (2004), pori-pori kecil mengakibatkan film berbahan dasar pati memiliki laju transmisi rendah terhadap uap air dan gas. Film berbahan dasar pati dengan penambahan sorbitol sebagai plasticizer memiliki permeabilitas yang rendah terhadap uap air jika dibandingkan dengan glikol, gliserol, polietilen glikol, maupun sukrosa pada konsentrasi yang sama (McHugh dan Krochta, 1994). Faktor-faktor yang mempengaruhi konstanta permeabilitas kemasan adalah jenis film, ada tidaknya "cross linking", ada tidaknya plasticizer, jenis polimer film, sifat dan besar molekul gas, solubilitas atau kelarutan gas (Syarief et al., 1989).

Kelarutan dalam air yaitu untuk memprediksi kestabilan bioplastik terhadap pengaruh air. Hasil analisis menunjukkan bahwa dengan adanya penambahan masing-masing variasi komposisi mempengaruhi sifat fisik kelarutan dalam air. Besarnya kelarutan suatu zat dalam suatu pelarut dipengaruhi oleh sifat dan intensitas kekuatan serta interaksi antara zat terlarut dan pelarutnya. Menurut Thirathumthavorn dan Charoenrein (2006), menurunnya daya larut juga disebabkan karena amilosa dengan gugus subtituen membentuk ikatan yang sangat kuat sehingga menyebabkan terjadi pemerangkapan molekul air di dalam molekul pati, yang mengakibatkan swelling power meningkat dan mencegah molekul amilosa untuk terlarut dalam sistem yang menyebabkan daya larut pati menurun. Gambar 5 memperlihatkan pengaruh penambahan sorbitol dan kalsium karbonat dari berbagai variasi komposisi terhadap persentase kelarutan dalam air. Penambahan kalsium karbonat meningkatkan kelarutan dalam air walaupun tidak begitu signifikan. Hal ini diduga karena ion kalsium $\left(\mathrm{Ca}^{2+}\right)$ berikatan dengan dengan gugus hidroksil pada pati sehingga membentuk suatu jaringan. Kalsium karbonat yang dilarutkan dalam larutan pati dari kulit pisang akan berbentuk partikel-partikel kecil, apabila partikel tersebut masuk kedalam struktur pati maka struktur tersebut akan meregang membentuk rongga-rongga yang memudahkan air masuk ke dalam struktur. Semakin banyak air yang masuk ke dalam struktur pati akan meningkatkan kelarutan dalam air dan asam. Penambahan sorbitol pada film meningkatkan kelarutan dalam air. Hal ini karena sorbitol memiliki sifat hidrofil. Menurut Bourtoom (2007), jenis dan konsentrasi dari plasticizer yang digunakan akan memberikan pengaruh terhadap kelarutan dari film berbahan dasar pati. Semakin banyak penggunaan plasticizer maka akan meningkatkan kelarutan. 


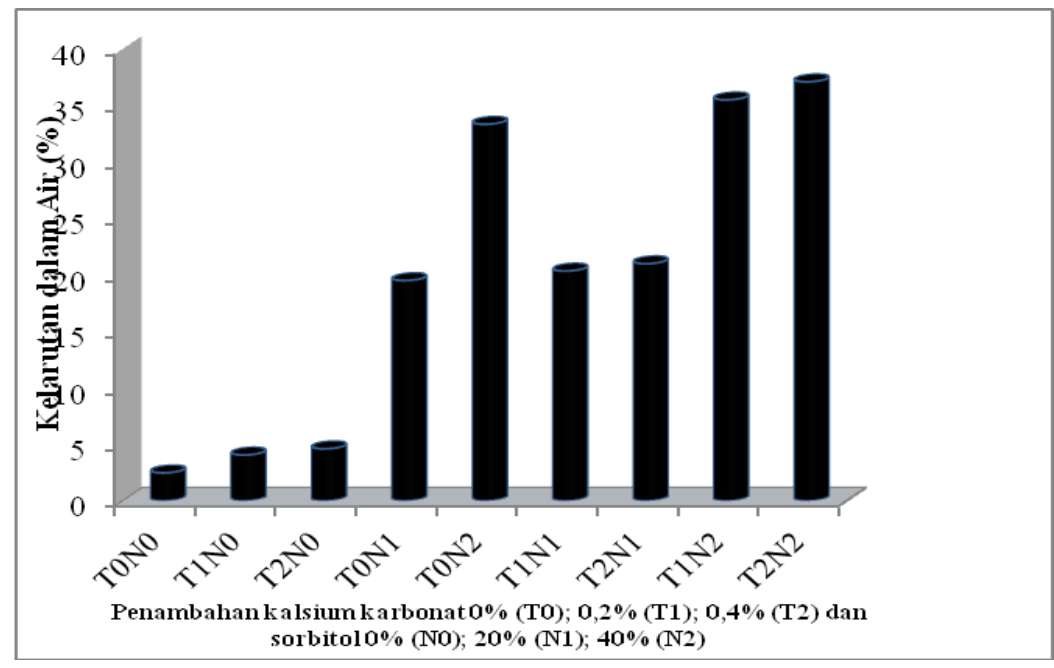

Gambar 5. Diagram pengaruh penambahan sorbitol dan kalsium karbonat terhadap sifat kelarutan dalam air film

Kelarutan dalam asam yaitu untuk memprediksi kestabilan bioplastik terhadap hidrolisis oleh senyawa asam yang kemungkinan keluar dari bahan pangan selama penyimpanan. Persentase kelarutan bioplastik dalam asam lebih besar daripada air, hal ini karena pati lebih mudah terdegradasi oleh asam dan pati tidak tahan dalam kondisi asam. Hasil analisis persentase kelarutan dalam asam terbesar yaitu pada T2N2 (penambahan 0,4\% kalsium karbonat dan $40 \%$ sorbitol) yaitu sebesar $87,86 \%$. Hal ini karena plasticizer yang digunakan yaitu bersifat hidrofil dan dengan adanya penambahan $\mathrm{CaCO}_{3}$ pada larutan pati, akan membentuk partikel-partikel yang akan masuk ke dalam struktur pati sehingga struktur akan meregang membentuk rongga dan air atau asam akan mudah masuk dan menyebabkan kelarutan meningkat. Ketebalan film mempengaruhi kelarutannya, artinya semakin tebal film maka semakin rendah daya larutnya karena kekompakan film sebagai akibat dari meningkatnya ikatan hidrogen seiring dengan meningkatnya ketebalan film. Ikatan hidrogen yang semakin meningkat mengakibatkan struktur molekul pati saling kuat berikatan membentuk jaringan yang kompak, sehingga menurunkan daya larut film. Gambar 6 adalah diagram yang menunjukkan pengaruh penambahan sorbitol dan kalsium karbonat terhadap film.

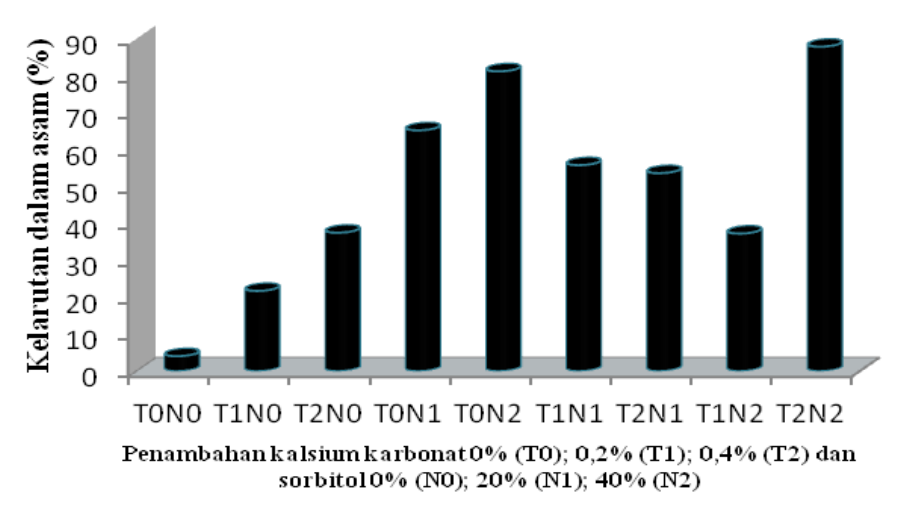

Gambar 6. Diagram pengaruh penambahan sorbitol dan kalsium karbonat terhadap sifat kelarutan dalam asam film 


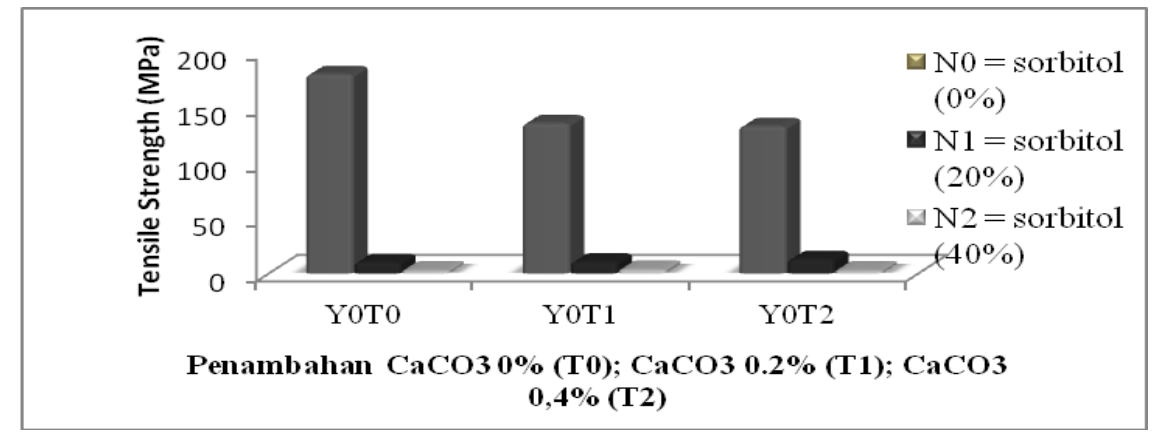

Gambar 7. Diagram pengaruh penambahan sorbitol dan kalsium karbonat terhadap daya regang film

Penentuan daya regang (tensile strength) atau sering dikenal juga sebagai kuat tarik merupakan gaya maksimum yang terjadi pada film selama pengukuran berlangsung. Hasil pengukuran ini berhubungan erat dengan jumlah plasticizer yang ditambahkan pada proses pembuatan film. Berdasarkan penelitian nilai daya regang tanpa penambahan sorbitol memiliki nilai lebih besar dibandingkan dengan adanya penambahan sorbitol. Plasticizer dapat mengurangi ikatan hidrogen internal molekul dan menyebabkan melemahnya gaya tarik intermolekul rantai polimer yang berdekatan sehingga mengurangi daya regang putus. Penambahan plasticizer lebih dari jumlah tertentu akan menghasilkan film dengan kuat tarik yang lebih rendah (Lai et al., 1997). Kalsium karbonat merupakan bahan pengisi pada penelitian ini. Secara umum, pengisi merupakan berbagai padatan, cairan, atau gas. Kalsium karbonat ditambahkan ke dalam matriks dengan tujuan meningkatkan sifat-sifat mekanik plastik melalui penyebaran tekanan yang efektif di antara serat dan matriks. Gambar 7 menunjukkan bahwa penambahan sorbitol dan kalsium karbonat menurunkan daya regang film.

Panjang putus (elongation at break) atau proses pemanjangan merupakan perubahan panjang maksimum pada saat terjadi peregangan hingga sampel film terputus. Pada umumnya adanya penambahan plasticizer dalam jumlah lebih besar akan menghasilkan nilai persen pemanjangan suatu film semakin lebih besar. Menurut Liu dan Han (2005), tanpa penambahan plasticizer, amilosa dan amilopektin akan membentuk suatu film dan struktur dengan satu daerah kaya amilosa dan amilopektin. Interaksi-interaksi antara molekul-molekul amilosa dan amilopektin mendukung formasi film, menjadikan film pati jadi rapuh dan kaku (Zhang dan Han, 2006). Persentase strain atau elongation terbesar pada film bioplastik berbahan dasar pati dari kulit pisang pada berbagai variasi komposisi yaitu T2N2 (penambahan 0,4\% kalsium karbonat dan $40 \%$ sorbitol) sebesar 19,81\% (Gambar 8). Hasil analisis memperlihatkan bahwa penambahan sorbitol berbanding lurus dengan persentase strain atau elongation, artinya semakin besar penambahan sorbitol maka semakin besar nilai persentase strain atau elongation. Penambahan plasticizer mampu mengurangi kerapuhan dan meningkatkan fleksibilitas film polimer dengan cara mengganggu ikatan hidrogen antara molekul polimer yang berdekatan sehingga kekuatan tarik-menarik intermolekul rantai polimer menjadi berkurang. Mekanisme proses plasticizer polimer sebagai akibat penambahan plasticizer berdasarkan Di Gioia dan Guilbert (1999), yaitu melalui adsorbsi, pemecahan, difusi, pemutusan pada bagian amorf, dan pemotongan struktur. 


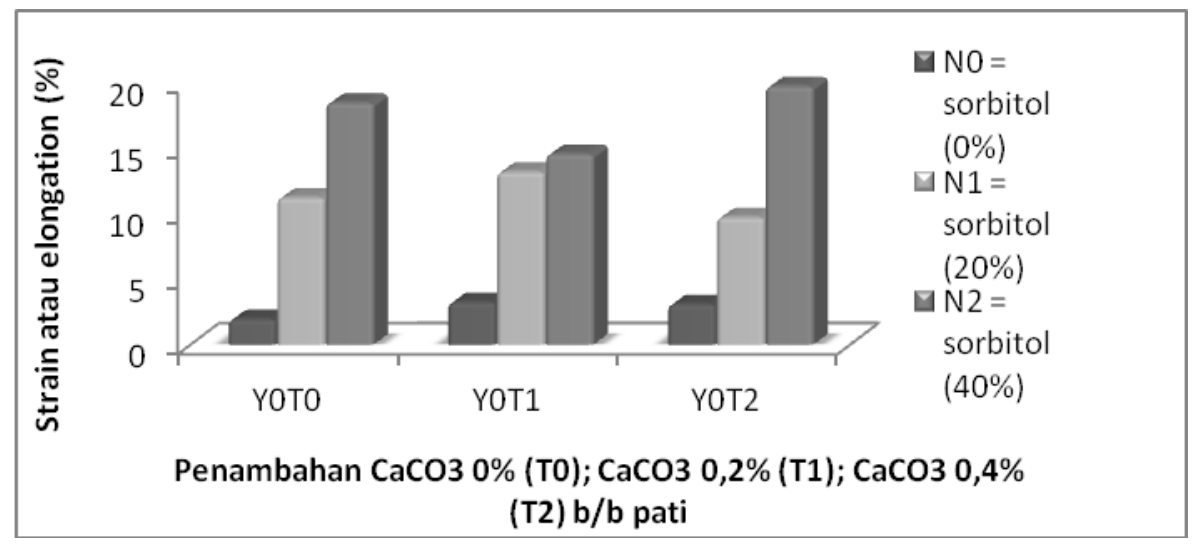

Gambar 8. Diagram pengaruh penambahan sorbitol dan kalsium karbonat terhadap nilai perpanjangan putus film

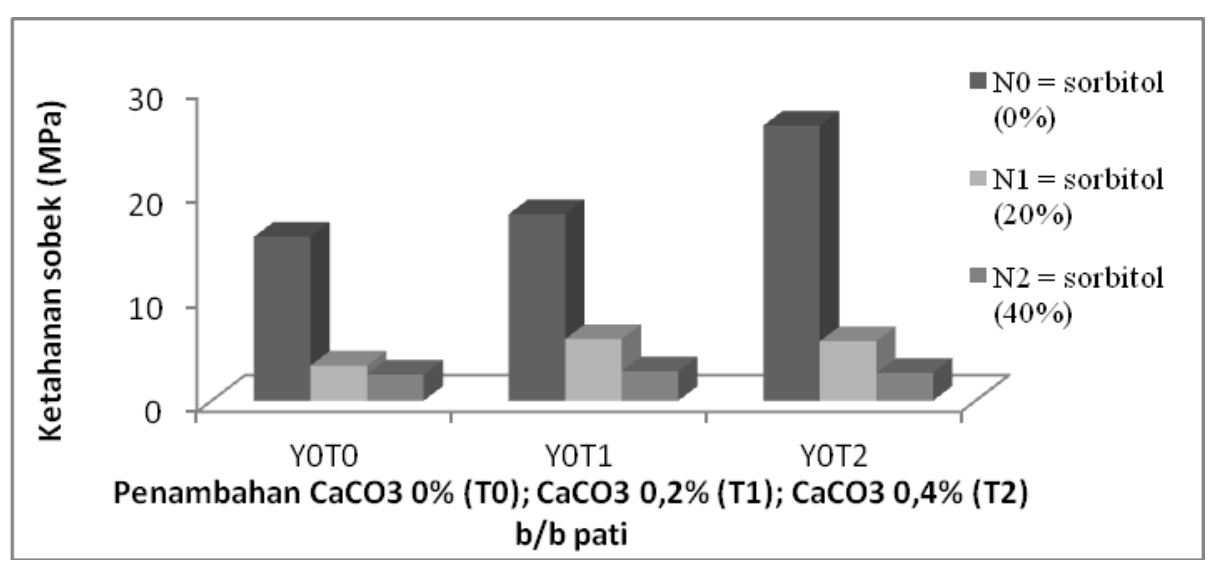

Gambar 9. Diagram pengaruh penambahan sorbitol dan kalsium karbonat terhadap sifat ketahanan sobek film

Hasil analisis uji F (sidik ragam) pada ketahanan sobek menunjukan bahwa adanya variasi komposisi penambahan sorbitol dan kalsium karbonat memberikan pengaruh sangat nyata. Ketahanan sobek merupakan gaya tarik maksimum yang dapat dicapai sampai film tetap bertahan sebelum film kemudian putus atau sobek (Krochta dan Johnson, 1997). Hasil penelitian menunjukkan bahwa ketahanan sobek pada film bioplastik dari berbagai variasi komposisi kalsium karbonat dan sorbitol berkisar antara 2,50-26,32 $\mathrm{MPa}$ seperti pada Gambar 9. Penambahan konsentrasi sorbitol meurunkan nilai ketahanan sobek. Bentuk, jumlah atom karbon dalam rantai dan jumlah gugus hidroksil yang terdapat dalam molekul plasticizer akan mempengaruhi sifat mekanis suatu film. Penambahan plasticizer akan mengurangi kekuatan ikatan hidrogen intermolekul polimer sehingga mengurangi ketahanan sobek dan meningkatkan fleksibilitas film

\section{c. Sifat biodegradable film}

Suatu bahan dikatakan biodegradable apabila bahan tersebut dapat mengikuti siklus hidup biomassa, termasuk konversi sumber fosil, air, dan produksi $\mathrm{CO}_{2}$. Kecepatan biodegradasi tergantung pada temperature $\left(50-60^{\circ} \mathrm{C}\right)$, kelembaban, jumlah dan tipe mikroba. Biodegradasi berjalan cepat jika ketiga persyaratan tersebut terpenuhi (Siracusa, 2008). 


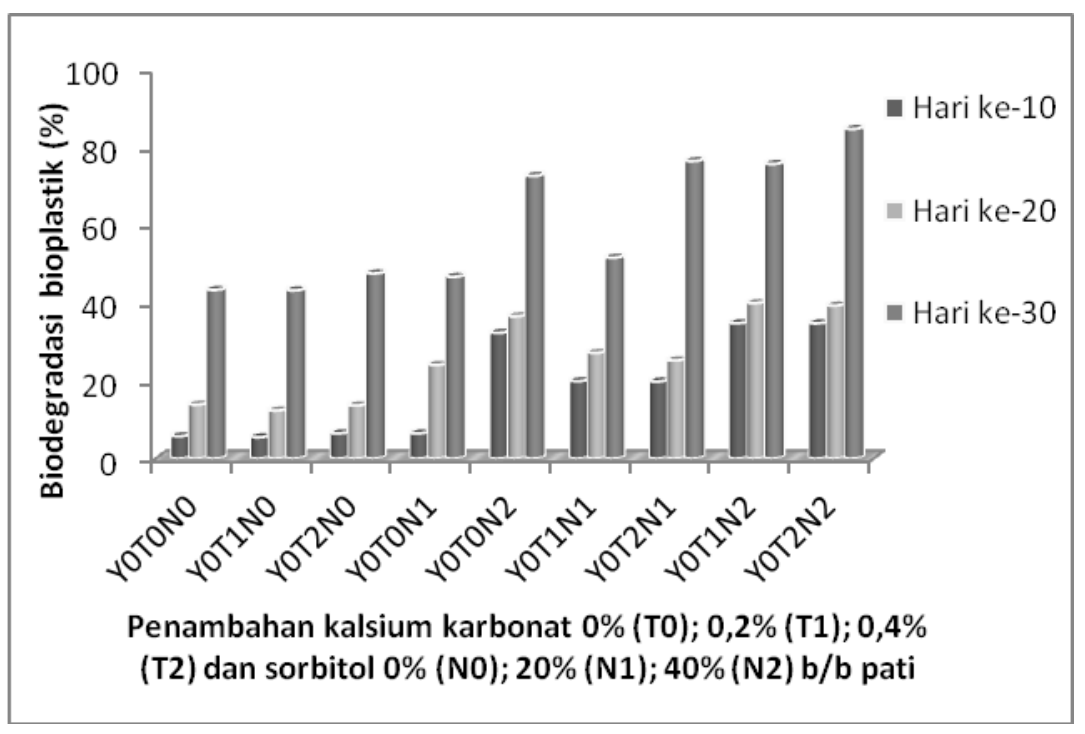

Gambar 10. Diagram pengaruh penambahan sorbitol dan kalsium karbonat terhadap sifat biodegradasi film

Uji biodegradasi film bioplastik berbahan dasar pati kulit pisang dilakukan dengan cara penguburan film bioplastik dalam tanah. Tanah yang digunakan pada penelitian ini yaitu tanah andesol. Penguburan film dilakukan selama 30 hari dan dilakukan penimbangan film setiap 10 hari. Persentase biodegradasi film bioplastik berbahan dasar pati dengan penambahan variasi komposisi kalsium karbonat dan sorbitol dapat dilihat pada Gambar 10.

Hasil uji biodegradasi bioplastik berbahan dasar pati dari kulit pisang menunjukkan pada hari ke-10 sudah mengalami penurunan berat film bioplastik dan mengalami meningkatan persentase penurunan berat film bioplastik terbesar yaitu setelah penguburan pada hari ke-30. Pati memiliki ikatan-ikatan asetal yang sangat mudah untuk diuraikan. Menurut Surdia (2000), degradasi polimer digunakan untuk menyatakan perubahan fisik akibat reaksi kimia yang mencakup pemutusan ikatan dalam tulang punggung dari makro molekul. Reaksi degradasi kimia dalam polimer linier menyebabkan turunnya berat molekul atau pemendekan panjang rantai. Penambahan sorbitol dan kalsium karbonat mempengaruhi sifat biodegradable flim. Semakin besar penambahan maka semakin besar pula persentase penurunan berat film.

\section{KESIMPULAN}

Penambahan sorbitol sebagai plasticizer dan kalsium karbonat sebagai filler mempengaruhi sifat fisik dan mekanik film dari pati kulit pisang. Penambahan sorbitol dan kalsium karbonat akan menambah nilai densitas, higroskopisitas, WVTR, kelarutan dalam air, kelarutan dalam asam, perpanjangan putus, dan ketahanan sobek serta menurunkan nilai daya regang putus film. Penambahan sorbitol dan kalsium karbonat juga mempengaruhi sifat biodegradasi film. Semakin banyak penambahan sorbitol dan kalsium karbonat maka semakin besar persentase kehilangan berat film dari pati kulit pisang. 
DAFTAR PUSTAKA

AOAC, 1995, Official Methods of Analysis, Association of Analitical Chemist, Washington D.C.

Averous, L., 2004, Biodegradable Multiphase System Based on Plasticized Starch : A Review, Journal of Macromolecular Science, United Kingdom.

Bourtoom, T., 2007, Effect of Some Process Parameters on The Properties of Edible Film Prepared From Starch, Department of Material Product Technology, Songkhala.

Careda, M.P., C.M., Henrique, M.A., de Oliveira, M.V., Ferraz, N.M., Vincentini, 2000, Characterization of Edible Films of Cassava Starch by Electron Microscopy, Braz, J. Food Technol, Vol. 3, 91-95.

Darni, Y., A., Chici, \& I.D., Sri., 2008, Sintesa Bioplastik dari Pati Pisang dan Gelatin dengan Plasticizer Gliserol, Seminar Nasional Sains dan Teknologi-II, Universitas Lampung, 17-18 November 2008

Di Gioia, L., \& Guilbert, S., 1999, Corn Protein-Based

Thermoplasticresins: Effect of Some Polar and Amphiphilic Plasticizers, J. Agric.Food Chem, Vol. 47, 1254-1261.

Gontard, N.S., Guilbert, \& J.L., Cuq, 1993, Water and Glycerol as Plasticizer effect mechanical and Water Vapor Barrier Properties of an Edible Wheat Gluten Film, $J$. Food Sci., Vol. 58, No. 1, 206-211.

Krochta \& D.M., Johnston, 1997, Edible and Biodegradable Polymers Film: Challenges and
Opportunities, J. Food Technologi, Vol. 51, No. 2, 61-74.

Lai, H.M., G.W., Padua \& L.S., Wei, 1997, Properties and Microsrucure of Zein Sheets Plastisized With Palmitic And Stearic Acids, Cereal Chem, Vol. 74, No. 1, 83-90.

Liu, Z. \& J.H., Han, 2005, Film Forming Characteristics of Starches, $J$. Food Science, Vol. 70, No. 1, E31E36.

McHugh, T.H. \& J.M., Krochta, 1994, Sorbitol vs Glycerol Plasticed Whey Protein Edible Film : Integrated Oxygen Permeability and Tensite Property Evaluation. J.Agic and food Chem, Vol. 2, No.4, 841-845.

Munadjim, 1983, Teknologi Pengolahan Pisang, PT Gramedia Pustaka Utama, Jakarta.

Santoso, B., D., Saputra, \& R., Pambayun, 2004, Kajian Teknologi Edible Coating dari Pati dan Aplikasinya Untuk Pengemas Primer Lempok Durian, Jurnal Teknol dan Industri Pangan XV (3).

Siracusa, V., P., Rocculi, S., Romani, M.D., Rosa, 2008, Biodegradable Polymers for Food Packaging: $A$ Review, Trendsin Food Science \& Technology, doi: 10.1016/j.tift.2008.07.003.

Surdia, N.M., 2000, Degradasi Polimer, Majalah Polimer Indonesia, Vol. 3, No.1, 20-21.

Syarief, R., Sasya, S., \& St. Isyana. B., 1989, Teknologi Penyimpanan Pangan. Penerbit, Pusat Antar Unit Pangan dan Gizi, ITB, Bandung, 376 hal.

Thirathumthavorn, D., \& S., Charoenrein, 2006, Thermal and Pasting 
Pengaruh penambahan sorbitol dan kalsium karbonat... (Senny Widyaningsih, dkk)

Properties of native and acidtreated starches derivatizdeed by I-Octenyl Succinicanhydride, Carbohydrate Polimer, 66:258265.doi:10.1016, j.carbpol, 2006,03,016.
Zhang, V., \& J.H., Han, 2006, Plastikization of Pes Starch Film With Monosaccharide and Polyols, Jurnal Food ist, Vol. 71, No. 6, 253-260. 